\title{
LIMBAH CAIR INDUSTRI KAKAO SEBAGAI BAHAN PEMBUAT NATA
}

\author{
YUNIANTA \\ Jurusan Teknologi Hasil Pertanian Universitas Brawijaya \\ E-mail: yuniantamlg@yahoo.com
}

\begin{abstract}
ABSTRAK
Penelitian ini ditujukan untuk memanfaatkan limbah cair dari industri kakao sebagai bahan pembuatan nata. Penelitian dibagi dalam dua tahap yaitu tahap penjernihan limbah cair industri kakao dengan arang aktif pada tingkat pengenceran berbeda serta studi tentang pengaruh konsentrasi sumber karbon (gula) dan konsentrasi sumber nitrogen yang ditambahkan terhadap pembentukan pelikel nata. Konsentrasi arang aktif dan perlakuan pengenceran berpengaruh terhadap parameter yang terkait dengan kejernihan limbah. Perlakuan terbaik diperoleh dari perlakuan konsentrasi arang aktif 5\% dengan pengenceran medium 1:3. Penelitian di tahap kedua dengan perlakuan pengaruh konsentrasi sumber karbon (gula sukrosa) dan sumber nitrogen menunjukan perlakuan terbaik diperoleh dari kombinasi perlakuan konsentrasi sukrosa $4 \%$ dan konsentrasi $\left(\mathrm{NH}_{4}{ }_{2} \mathrm{SO}_{4}\right.$ 0,4\%. Perlakuan terbaik ini memiliki nilai karakteristik produk nata meliputi rendemen: 83,87\%; kadar air: 95,23\%; serat kasar: 4,22\%; kecerahan ( $\left.L^{*}\right): 42,87$; tekstur: 0,01 mm/g.dt dan ketebalan: $2,42 \mathrm{~cm}$.
\end{abstract}

Kata kunci: limbah kakao, Arang aktif, Nata

\begin{abstract}
This research was aimed to utilize the liquid waste of cacao industry as raw material for nata production. Research was performed in two steps: the first steps was clarification process using active charcoal in different waste dilllutions and the second step was the production of nata. Result of first step showed that active charcoal concentration and dilution treatment showed their effect of all parameters studied. The best result was obtained by treatment of 5\% active charcoal concentration and the dilllution of cacao waste: water in 1:3 ratio. The production of nata in the second step of research was performed using this optimal clarification condition. Data showed that the combination treatment of $4 \%$ sucrose concentration and $0.4 \%$ of $\left(\mathrm{NH}_{4}\right)_{2} \mathrm{SO}_{4}$ was elected as the best process that gave the best quality of nata. The best treatment showed product characteristic: $83.87 \%$ of fermentation yield; $95.23 \%$ of moisture content; $4.22 \%$ of fiber content; brightness ( $\left.L^{*}\right)$ of 42.87 ; $0.01 \mathrm{~mm} / \mathrm{g} . \mathrm{dt}$ of textur and $2.42 \mathrm{~cm}$ of nata thickness.
\end{abstract}

Keywords: cacao waste, active charcoal, nata

\section{PENDAHULUAN}

Proses fermentasi pulp adalah merupakan proses yang utama dalam industri pengolahan biji kakao dan menentukan kualitas produk akhir. Tujuan dari fermentasi buah kakao adalah menghilangkan pulp, mematikan biji, membentuk warna dan calon flavor yang diinginkan serta memperbaiki rasa biji kakao. Selama proses tersebut senyawa polifenol (tannin) penyebab rasa kelat berdifusi ke seluruh jaringan biji dan merembes keluar dari keping biji. Senyawa tannin tersebut dapat berubah warna menjadi coklat dikarenakan teroksidasi oleh enzim polifenolase yang berakibat terjadinya perubahan warna kulit biji dan pulp yang berangsur-angsur menjadi coklat gelap (Siregar, et al.,1989).

Belitz dan Grosch (1987) menyatakan bahwa fermentasi pulp biji kakao segar oleh khamir dan bakteri akan menghasilkan cairan pulp (cacao sweating) yang berwarna keruh. Menurut Agyeman dan Oldham (1986) cairan pulp ini mempunyai $\mathrm{pH}$ 3,4-7,0 dan menurut Effendi (1995) cairan pulp segar mengandung gula $12-15 \%, 5-7 \%$ pektin, $0,8-1,5 \%$ asam tidak menguap dan 0,1-0,5\% protein. Cairan pulp dengan kandungan gula $12-15 \%$ berpotensi digunakan sebagai bahan dasar untuk produksi nata, namun diperlukan perlakuan pendahuluan untuk mengatasi warna cairan pulp yang cenderung berwarna gelap. Perlakuan pendahuluan yang dimaksud adalah penjernihan dengan cara pengenceran dan penyerapan senyawa penyebab warna gelap dengan menggunakan adsorban.

Penjernihan cairan pulp limbah industri kakao dengan arang aktif, selain akan mampu menghilangkan zat warna juga dapat menyerap 
senyawa-senyawa nitrogen. Adapun pengenceran akan berakibat berkurangnya konsentrasi senyawa warna, gula dan senyawa nutrisi sumber nitrogen yang sangat dibutuhkan untuk pertumbuhan bakteri Acetobacter xylinum. Penelitian ini bertujuan untuk mengetahui pengaruh cara penjernihan (perlakuan konsentrasi arang aktif dan faktor pengenceran) serta pengaruh konsentrasi gula dan sumber nitrogen terhadap kualitas nata yang dihasilkan.

\section{METODE}

Bahan baku utama dalam penelitian ini cairan pulp, limbah dari industri kakao yang diperoleh dari Kebun Bantaran PTPN XII Blitar. Bahan penjernih limbah cair kakao adalah arang aktif dari tempurung kelapa. Hal ini sesuai dengan pendapat dari Winarno (1997) yang menyatakan bahwa senyawa yang bertanggung jawab atas perubahan warna dalam pengolahan pangan terutama golongan fenol seperti antosianin, flavonoid, leukoantisianogen dan tannin. Protein atau pektin bereaksi dengan polifenol membentuk koloid yang menimbulkan kekeruhan. Penghilangan kekeruhan tersebut dapat dilakukan dengan menggunakan jasa enzim yang menghidrolisis protein atau pektin atau bahan penjernih dan adsorben seperti bentonit, gelatin dan arang aktif yang dapat menyerap polifenol atau protein.

Penelitian tahap I dilakukan dengan metode Rancangan Acak Kelompok (RAK) dengan dua (2) faktor yang masing-masing faktor terdiri dari tiga (3) tingkat. Faktor 1 adalah konsentrasi arang aktif yang terdiri dari 3 tingkat konsentrasi yaitu $1 \%$, 3\% dan 5\%. Faktor 2 adalah pengenceran yang terdiri dari pengenceran cairan pulp: air 3:1, 1:1 dan 1:3. Penelitian tahap II dilakukan dengan metode Rancangan Acak Lengkap (RAL) dengan 2 faktor yang masing-masing faktor terdiri dari 3 tingkat: Faktor 1: konsentrasi sukrosa 2,0\%, 4,0\%, $6,0 \%$, sedangkan Faktor 2 adalah konsentrasi amoniumsulfat $0,2 \%, 0,3 \%, 0,4 \%$. Semua perlakuan diulang sebanyak 3 kali.

Pengamatan atas beberapa parameter dilakukan pada (1) limbah cair industri kakao, (2) nata yang terbentuk dan (3) sisa medium fermentasi. Pengamatan pada limbah cair kakao meliputi $\mathrm{pH}$, gula total, total padatan terlarut, kekeruhan, serat kasar dan warna. Nata yang terbentuk dianalisis warna, tekstur, rendemen, ketebalan, dan serat kasarnya, sedangkan analisis $\mathrm{pH}$ dan gula total dilakukan terhadap sisa medium. Data dianalisis dengan menggunakan Uji Sidik Ragam (ANOVA). Uji beda nyata dilakukan dengan uji Beda Nyata Terkecil (BNT) dan apabila dari hasil uji menunjukkan adanya interaksi, maka dilakukan uji lanjut dengan menggunakan metode Duncan's Multiple Range Test $(D M R T)$. Pemilihan perlakuan terbaik ditentukan dengan menggunakan metode multiple atribute (Zelleny, 1992).

\section{HASIL DAN PEMBAHASAN}

Pada penelitian tahap I dipelajari pengaruh tingkat pengenceran $(3: 1,1: 1,1: 3)$ dan konsentrasi arang aktif (1\%, 3\% dan 5\%) terhadap sifat fisikokimia limbah cair kakao terjernihkan. Parameter yang diamati adalah kekeruhan, total padatan terlarut, kadar tannin, kecerahan, pH dan kadar gula total. Secara lengkap data penjernihan limbah cair kakao dapat dilihat di Tabel 2. Hasil analisis terhadap limbah cair kakao sebelum perlakuan adalah sebagai berikut: kekeruhan $\left(\mathrm{ppm} \mathrm{SiO}_{2}\right)$ 54,746, total padatan terlarut $22 \%$ Brix, kadar tannin sebesar $0,832 \%$, kecerahan $\left(\mathrm{L}^{*}\right) 24,2 ; \mathrm{pH} 3,5$ dan kadar gula total $20,275 \%$.

Kekeruhan pada limbah cair industri kakao dipengaruhi oleh senyawa-senyawa albuminoid, pektin, tannin, garam-garam mineral dan partikelpartikel pengotor seperti tanah, abu dan lainnya yang tersuspensi dalam limbah cair kakao. Analisis ragam menunjukkan adanya pengaruh nyata $(\alpha=$ $0,05)$ dari interaksi kedua perlakuan konsentrasi arang aktif dan pengenceran terhadap kekeruhan. Rerata kekeruhan semakin menurun dengan semakin meningkatnya konsentrasi arang aktif dan pengenceran. Hal ini terkait dengan semakin turunnya kepekatan dan jumlah partikel-partikel tersuspensi dalam cairan dan semakin tingginya daya serap terhadap senyawa warna. Perlakuan

Tabel 2. Kondisi akhir limbah industri kakao terjernihkan

\begin{tabular}{|c|c|c|c|}
\hline $\begin{array}{c}\text { Kondisi awal sebelum } \\
\text { penjernihan }\end{array}$ & Kondisi akhir setelah penjernihan & \multicolumn{2}{|c|}{ Kondisi Perlakuan Penjernihan } \\
\hline Kekeruhan $\left(\mathrm{ppm} \mathrm{SiO}_{2}\right) 54,746$ & Kekeruhan terendah $33,308 \mathrm{ppm} \mathrm{SiO}_{2}$. & Pengenceran 1:3 & Konsentrasi arang aktif 5\% \\
\hline Total padatan terlarut $22 \%$ Brix & $\begin{array}{l}\text { Total padatan terlarut terendah } 14,2 \% \\
\text { Brix }\end{array}$ & Pengenceran 1:3 & Konsentrasi arang aktif 5\% \\
\hline Kadar tannin $0,832 \%$ & Kadar tannin terendah $0,252 \%$. & Pengenceran 1:3 & Konsentrasi arang aktif 5\% \\
\hline Kecerahan $\left(\mathrm{L}^{*}\right) 24,2$ & Kecerahan $\left(\mathrm{L}^{*}\right)$ tertinggi 32,633 & Pengenceran 1:3 & Konsentrasi arang aktif 5\% \\
\hline \multirow[t]{2}{*}{ Total gula $20,275 \%$} & Total gula tertinggi $18,301 \%$ & Pengenceran 3:1 & Konsentrasi arang aktif $1 \%$ \\
\hline & Total gula Terendah $10,246 \%$ & Pengenceran 1:3 & Konsentrasi arang aktif 5\% \\
\hline
\end{tabular}


konsentrasi arang aktif 1\% dan pengenceran 3:1 memberikan kekeruhan tertinggi yaitu 42,446 ppm $\mathrm{SiO}_{2}$, sedangkan perlakuan konsentrasi arang aktif 5\% dan pengenceran 1:3 memberikan kekeruhan terendah yaitu $33,308 \mathrm{ppm} \mathrm{SiO}_{2}$.

Dalam hal total padatan terlarut, perlakuan konsentrasi arang aktif 1\%, 3\% dan 5\% berturutturut mengakibatkan nilai total padatan terlarut sebesar 16,056\% Brix $^{\mathrm{b}} ; 14,9 \% \mathrm{Brix}^{\mathrm{ab}}$ dan 14,2\% Brix $^{\mathrm{a}}$. Hal ini diduga karena adanya penyerapan senyawasenyawa terlarut (bukan gula) seperti nitrogen dan tannin oleh arang aktif. Nilai total padatan terlarut pada pengenceran $3: 1 ; 1: 1$ dan 1:3 berturut-turut adalah 18,967\% Brix $^{\mathrm{c}} ; 14,867 \% \mathrm{Brix}^{\mathrm{b}}$ dan $11,322 \%$ Brix $^{\mathrm{a}}$. Hasil analisis ragam menunjukkan bahwa perlakuan konsentrasi arang aktif dan pengenceran berpengaruh sangat nyata $(\alpha=0,01)$ terhadap total padatan terlarut, sedangkan interaksi keduanya tidak berpengaruh nyata.

Kemampuan adsorpsi senyawa tannin oleh arang aktif ditunjukkan oleh efek perlakuan konsentrasi arang aktif $1 \%, 3 \%$ dan $5 \%$ yang memberikan kadar tannin berturut-turut $0,581 \%^{\mathrm{c}} ; 0,329 \%^{\mathrm{b}}$ dan $0,252 \%^{\mathrm{a}}$. Adapun tingkat pengenceran yang meningkat dari pengenceran $3: 1$; $1: 1$ dan 1:3 menyebabkan kadar tannin berturut-turut sebesar $0,443 \%$; $; 0,388 \%$ dan $0,332 \%$. Hasil analisis ragam menunjukkan bahwa perlakuan konsentrasi arang aktif dan pengenceran memberikan pengaruh yang sangat nyata $(\alpha=0,01)$ terhadap kadar tannin, sedangkan interaksi kedua perlakuan tidak berpengaruh nyata.

Penurunan warna pada limbah cair kakao setelah penjernihan dapat dinyatakan dalam nilai kecerahan $\left(L^{*}\right)$, dimana penurunan warna akan meningkatkan nilai kecerahannya. Hasil analisis ragam dan uji statistik menunjukkan bahwa perlakuan konsentrasi arang aktif 1\%, 3\% dan 5\% memberikan pengaruh sangat nyata $(\alpha=0.01)$ pada nilai kecerahan berturut-turut $29,817^{\mathrm{a}} ; 31,769^{\mathrm{b}}$ dan $32,200^{\mathrm{b}}$. Perlakuan pengenceran $3: 1 ; 1: 1$ dan $1: 3$ menunjukkan pengaruh sangat nyata $(\alpha=0,01)$ terhadap tingkat kecerahan medium awal dengan nilai berturut-turut $30,178^{\mathrm{a}} ; 31,444^{\mathrm{b}}$ dan $32,633^{\mathrm{c}}$.

Analisis korelasi antara kecerahan dengan tingkat kekeruhan dan kadar tannin berturutturut menghasilkan persamaan korelasi $\mathrm{y}=-0,433 \mathrm{x}+47,777\left(\mathrm{R}^{2}=0,7736\right)$ dan $\mathrm{y}=-8,2801 \mathrm{x}+$ $34,471\left(R^{2}=0,8408\right)$. Korelasi antara kekeruhan dan kecerahan $\left(\mathrm{L}^{*}\right)$, menunjukkan bahwa semakin tinggi kekeruhan maka kecerahannya semakin menurun dan sebaliknya. Adapun korelasi kecerahan dengan kadar tannin menunjukkan bahwa semakin tinggi kadar tannin maka akan meningkatkan warna gelap dan berarti semakin rendah tingkat kecerahan cairan limbah.
Kadar gula total cenderung tetap dan hasil analisis ragam menunjukkan bahwa tidak ada pengaruh nyata dari perlakuan konsentrasi arang aktif. Diduga hal tersebut disebabkan oleh perbedaan tingkat polaritas antara gula dan arang aktif, dimana gula bersifat polar sedangkan menurut Weber (1977) arang aktif termasuk adsorben yang bersifat non polar. Hal yang sebaliknya terjadi pada perlakuan pengenceran, di mana tingkat pengenceran berpengaruh sangat nyata $(\alpha=0,01)$ terhadap kadar gula total yaitu $18,301 \%^{\mathrm{c}}, 13,934 \%^{\mathrm{b}}$ dan $10,608 \%$. Berdasarkan hasil yang tersaji di Tabel 2, maka dapat disimpulkan bahwa perlakuan penjernihan limbah industri kakao terbaik dilakukan dengan menggunakan arang aktif 5\% dengan tingkat pengenceran 1:3.

Dalam penelitian tahap kedua, limbah cair coklat hasil penjernihan di tahap pertama yang mempunyai kadar gula reduksi 11,476\% digunakan sebagai bahan baku dalam proses fermentasi dengan menggunakan Axylinum untuk mendapatkan produk nata. Pada penelitian tahap kedua ini, dipelajari pengaruh perlakuan konsentrasi sukrosa $2 \%, 4 \%$ dan $6 \%$ dan perlakuan konsentrasi (NH4) ${ }_{2} \mathrm{SO}_{4} 0,2 \%$; $0,3 \%$ dan $0,4 \%$ terhadap beberapa parameter yang meliputi: kadar gula reduksi sisa medium fermentasi, ketebalan nata, kadar serat kasar nata dan rendemen nata.

Hasil percobaan menunjukkan bahwa perlakuan konsentrasi sukrosa berpengaruh sangat nyata $(\alpha=$ $0,01)$ terhadap gula reduksi sisa medium fermentasi berturut-turut sebesar $1,09 \%^{\mathrm{a}} ; 1,34^{\mathrm{a}} \%^{\mathrm{a}} ; 2,16 \%^{\mathrm{b}}$ dan pengaruh nyata $(\alpha=0,05)$ terhadap $\mathrm{pH}$ sisa fermentasi berturut-turut sebesar $3,15^{\mathrm{b}}, 3,0^{\mathrm{a}}$ dan $3,09^{\text {ab }}$. Aktifitas A. xylinum selama proses fermentasi telah menghasilkan metabolit primer dalam bentuk selulosa maupun sekunder dalam bentuk asam asam organik dilakukan dengan menggunakan gula sebagai sumber karbon. Konsentrasi $\left(\mathrm{NH}_{4}\right)_{2} \mathrm{SO}_{4}$ dan interaksi kedua perlakuan tidak berpengaruh nyata terhadap gula reduksi dan $\mathrm{pH}$ sisa medium fermentasi.

Perlakuan konsentrasi sukrosa $2 \%, 4 \%$ dan $6 \%$ berpengaruh sangat nyata $(\alpha=0,01)$ pada ketebalan nata yang dihasilkan berturut-turut $1,71 \mathrm{~cm}^{\mathrm{a}}$, $2,23 \mathrm{~cm}^{\text {b }}$ dan $1,92 \mathrm{~cm}^{\text {ab }}$. Data ketebalan nata tertinggi diperoleh pada konsentrasi sukrosa 4\%. Dalam proses fermentasi tersebut, pertumbuhan bakteri Axylinum optimum memerlukan kadar gula reduksi kira-kira 19,48\% dengan asumsi $4 \%$ sukrosa setara dengan $8 \%$ gula reduksi ditambah dengan kadar gula reduksi awal fermentasi $11,48 \%$. Rendahnya ketebalan nata pada konsentrasi $6 \%$, dimungkinkan karena kadar gula reduksi didalam medium sudah terlalu tinggi yaitu sekitar $23,48 \%$. Pada kadar gula tersebut 
diduga pertumbuhan $A$ xylinum dan produksi nata menjadi terhambat.

Perlakuan konsentrasi (NH4) ${ }_{2} \mathrm{SO}_{4}$ berpengaruh nyata $(\alpha=0,05)$ terhadap ketebalan nata berturutturut $1,74 \mathrm{~cm}^{\mathrm{a}}, 1,96 \mathrm{~cm}^{\mathrm{ab}}$ dan $2,15 \mathrm{~cm}^{\mathrm{b}}$. Pembentukan produk nata terbaik pada kadar $\left(\mathrm{NH}_{4}\right)_{2} \mathrm{SO}_{4} 0,4 \%$. Pertumbuhan bakteri A. xylinum memerlukan sumber nitrogen dimana penambahan $\left(\mathrm{NH}_{4}\right)_{2} \mathrm{SO}_{4}$ sampai 0,4\% masih direspons secara positip dan tidak menunjukkan gejala penghambatan pertumbuhan bakteri.

Perlakuan konsentrasi sukrosa dan konsentrasi $\left(\mathrm{NH}_{4}\right)_{2} \mathrm{SO}_{4}$ keduanya memberikan berpengaruh nyata $(\alpha=0,05)$ terhadap serat kasar nata yang dihasilkan. Perlakuan konsentrasi sukrosa menghasilkan kadar serat kasar berturut-turut $3,54 \%^{\mathrm{a}} ; 4,05 \%^{\mathrm{b}}$ dan $3,81 \%$ ab , sedangkan perlakuan konsentrasi $\left(\mathrm{NH}_{4}\right)_{2} \mathrm{SO}_{4}$ menghasilkan berturut-turut $3,56 \%^{\mathrm{a}}, 3,81 \%^{\mathrm{ab}}$ dan $4,03 \%^{\mathrm{b}}$ serat kasar. Pembentukan serat kasar terbaik terjadi pada kadar gula reduksi 19,48\% dan menurun saat kadar gula reduksi kira-kira 23,48\%. Sementara itu kecukupan nitrogen dalam medium akan menstimulir bakteri dalam mensintesa selulosa (Lapuz et al, 1967) sehingga menghasilkan nata dengan ikatan selulosa yang kuat dan jalinan yang rapat sehingga kandungan seratnya meningkat.

Serat selulosa adalah komponen utama dari nata yang terbentuk selama proses fermentasi dan kadar serat terkait erat dengan tekstur nata. Semakin besar kadar serat selulosa, nilai tekstur nata semakin rendah atau semakin kenyal. Hasil penelitian menunjukkan perlakuan konsentrasi sukrosa dan konsentrasi $\left(\mathrm{NH}_{4}\right)_{2} \mathrm{SO}_{4}$ berpengaruh nyata $(\alpha=0,05)$ terhadap tekstur nata. Perlakuan konsentrasi sukrosa menghasilkan tekstur nata berturut-turut $0,02 \mathrm{~mm} / \mathrm{g} \cdot \mathrm{dt}^{\mathrm{b}}, 0,01 \mathrm{~mm} / \mathrm{g} \cdot \mathrm{dt}^{\mathrm{a}} \mathrm{dan}$ $0,02 \mathrm{~mm} / \mathrm{g} \cdot \mathrm{dt}^{\mathrm{ab}}$, sementara perlakuan konsentrasi $\left(\mathrm{NH}_{4}\right)_{2} \mathrm{SO}_{4}$ memberikan tekstur nata berturut-turut 0,02 mm/g.dt ${ }^{\mathrm{b}}, 0,01 \mathrm{~mm} / \mathrm{g} \cdot d \mathrm{t}^{\mathrm{ab}}$ dan 0,01 mm/g.dta .

Ketebalan dan kadar serat kasar terkait erat dengan rendemen nata. Kecenderungan kadar serat dan ketebalan sebagai akibat dari perlakuan konsentrasi sukrosa dan konsentrasi sumber nitrogen juga ditemukan pada rendemen nata. Hasil penelitian menunjukkan bahwa perlakuan konsentrasi sukrosa $2 \%, 4 \%$ dan $6 \%$ berpengaruh nyata $(\alpha=0,05)$ terhadap rendemen nata sebesar berturut-turut $61,619 \%^{\mathrm{a}}, 80,702 \%^{\mathrm{b}}, 70,217 \%$ ab . Adapun perlakuan konsentrasi $\left(\mathrm{NH}_{4}\right)_{2} \mathrm{SO}_{4} 0,2 \% ; 0,3 \%$ dan $0,4 \%$ memberikan perbedaan yang nyata atas rendemen yang dihasilkan sebesar berturut-turut $61,74 \%^{\text {a }} ; 69,86 \%^{\text {ab }}$ dan $80,93 \%$.

Hasil analisis ragam menunjukkan bahwa perlakuan konsentrasi sukrosa berpengaruh sangat nyata $(\alpha=0,01)$ terhadap kecerahan nata namun tidak ada pengaruh nyata dari perlakuan konsentrasi $\left(\mathrm{NH}_{4}\right)_{2} \mathrm{SO}_{4}$ maupun interaksi kedua perlakuan. Perlakuan konsentrasi sukrosa $2 \%, 4 \%$ dan $6 \%$ memberikan pengaruh yang nyata $(\alpha=0,05)$ terhadap kecerahan nata yang dihasilkan berturutturut $45,29\left(\mathrm{~L}^{*}\right)^{\mathrm{b}} ; 45,33\left(\mathrm{~L}^{*}\right)^{\text {a }}$ dan $43,23\left(\mathrm{~L}^{*}\right)^{\mathrm{a}}$.

Berdasarkan hasil pengujian tiap parameter tersebut dengan menggunakan metode multiple atribute (Zeleny,1992), maka diperoleh informasi bahwa perlakuan terbaik diperoleh dari kombinasi perlakuan konsentrasi sukrosa $4 \%$ dan konsentrasi $\left(\mathrm{NH}_{4}\right)_{2} \mathrm{SO}_{4} 0,4 \%$. Perlakuan terbaik ini memiliki nilai karakteristik produk yang meliputi rendemen $83,87 \%$, serat kasar 4,22\%; kecerahan $\left(\mathrm{L}^{*}\right) 42,87$; tekstur $0,01 \mathrm{~mm} / \mathrm{g}$.dt dan ketebalan nata 2,42 cm.

\section{SIMPULAN}

Limbah industri kakao dalam bentuk cairan pulp dapat dimanfaatkan sebagai bahan dasar pembuatan nata de cacao. Diperlukan pengenceran dan penjernihan dengan menggunakan arang aktif sebelum digunakan sebagai media fermentasi nata. Terdapat interaksi nyata $(\alpha=0,05)$ antar perlakuan konsentrasi arang aktif dan pengenceran pada tingkat kekeruhan dan warna kuning $\left(b^{*}\right)$ cairan limbah. Perlakuan terbaik diperoleh dari perlakuan konsentrasi arang aktif 5\% dengan pengenceran medium 1:3. Perlakuan konsentrasi sukrosa dan $\left(\mathrm{NH}_{4}\right)_{2} \mathrm{SO}_{4}$ memengaruhi secara nyata terhadap ketebalan, rendemen, kadar serat, kadar air dan tekstur nata, namun interaksi dari kedua perlakuan tidak berpengaruh nyata terhadap parameterparameter tersebut. Perlakuan terbaik diperoleh dari kombinasi perlakuan konsentrasi sukrosa $4 \%$ dan konsentrasi $\left(\mathrm{NH}_{4}\right)_{2} \mathrm{SO}_{4} 0,4 \%$.

\section{DAFTAR PUSTAKA}

Agyeman, K.O.G and Oldham, J.H., 1986. Utilization of Cacao By-product as an Alternatif Source of Energy Biomass. 10: 311-318.

Belitz, H.D. and Grosch, W., 1987. Food Chemistry. Springer Verlag. Berlin Hendelberg.

Effendi, S., 1995. Utilization of Cacao Sweatings for Nata Production Using Acetobacter Xylinum. Menara Perkebunan. 63(1): 23-26.

Lapuz, M.N., Bullardo, F.G. and Palo, M.A., 1967. The Nata Organism Cultural Requirment Characteristic and Identify. The Philipine Journal of Science. Vol. 9 (2).

Weber, J.T., 1977. Physicochemical Process for Water Quality Control. John Willey and Sons. New York.

Winarno, F.G., 1997. Kimia Pangan. Gramedia Pustaka Utama. Jakarta.

Zeleny, M., 1992. Multiple Kriteria Decision Making. McGraw-Hill. New York. 